\title{
The Invention of Time Units
}

\author{
*Patrice F Dassonville \\ Author of the Invention of Time and Space: Origins, Definitions, Nature, Properties, France
}

Submission: November 13, 2017; Published: November 27, 2017

*Corresponding author: Patrice F Dassonville, Author of The Invention of Time and Space: Origins, Definitions, Nature, Properties, Rue LatourMaubourg, 06400 Cannes, France, Email: patrice.f.dassonville@gmail.com

\section{Short Communication}

In ancient times, natural phenomena have gradually been used as references to help improve the organization of everyday life. Unfortunately, Our investigation is forced to Start after the tempus mutum a literis (the silent age without writing) deplored by the Roman statesman Cicero (106-43) in his Correspondance. In the following, it is crucial not to confuse a reality, which is observable, and the Corresponding concept, which is a construction of the mind : the conceptualization - from reality to concept - is illustrated below with the example of the approach of the Sumerians.

\section{The first units}

In northwestern Mali, since over two thousand years, the Dogon have an important religious holiday called Sigi. A Sigi lasts during eight low waters of Niger (8 years), and it takes place every sixty low waters of the river (60 years). Scholars and ancients use the sigi as a unit, to tell their long history. (Dieterlin).

The sigi, as a unit, is defined compared to low waters, which are observed :

The sigi is a unit which corresponds to 60 law waters

The observation of solar alternations led the Maya to invent the kin. (Brion), which corresponds to one day.

The day, as a unit, is defined compared to a solar procession:

The day is a unit which corresponds to one solar procession

The Greek Games were set up in honor of Zeus at Olympia in the Peloponnese. From 776 BC, a list of winners was established, and this date is considered to be the beginning of Greek chronology. The olympiad thereby became a kind of time unit, equivalent to four years.

The olympiad is defined compared to two successive Games:

The olympiade is a unit corresponding to what separates two Games

The Jewish historian Flavius Yossipos (37-c.100) recalled that The Temple of Jerusalem was taken (by Pompey) on a day of fasting during the 179th olympiad. (Book 7, 2), which would have been about $60 \mathrm{BC}$. In Timaeus, the Greek philosopher Plato (428-c.348) wrote : the Sun, the Moon, and the five other stars were born to define the numbers of the time. (Conteneau). He's right, as the numbers of the time correspond to our time units. Unfortunately, he added that days, nights, seasons, were the divisions of time; which shows us that Plato did not differentiate phenomena (days, nights, seasons) and concepts (divisions of time). In Sumer (lower Mesopotamia) : Archeology has unearthed a clay tablet dated between 2800 and 2500 BC . It wears a cuneiform sign arhue, which means lunar month. (Conteneau) (Figure 1). It's the first trace of time in history [1$10]$.

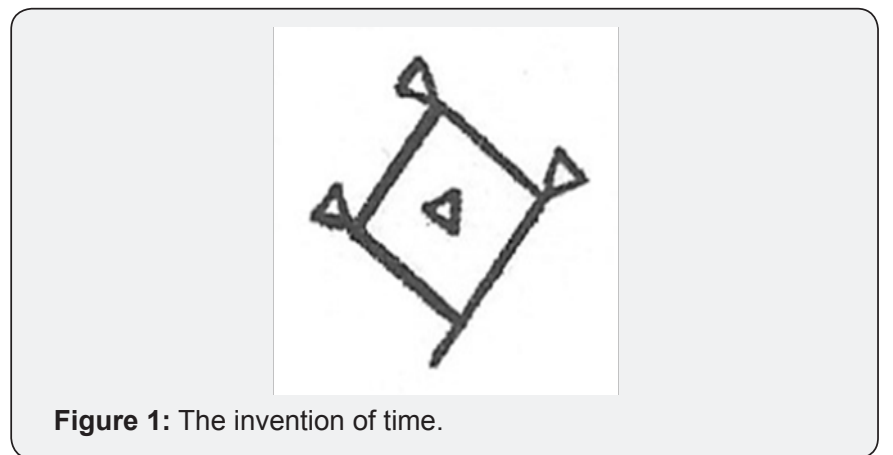

The mental approach of the Sumerian scholars deserves to be analysed:

a) they observed the motion of the Moon,

b) they noted the passage of the Moon repeated (now called lunation),

c) they used it as a reference (now called unit),

d) they called this reference arhue, an unprecedented concept which corresponds to the lunar month.

The lunar month is defined compared to the lunation :

The lunar month is a unit which corresponds to a lunation 


\section{The Erratic Value of The Year}

In Egypt : The Greek biographer Plutarch (c.46-c.126) writes that the year had one month first, and then four months. (Life of Numa, 18, 7). The Egyptians assure the Greek historian Herodotus (484-425) that they were the first to spot the cycle of the seasons, divided into twelve months. (Book II, 4). At the beginning of the third millennium, the Egyptians used a civil calendar including one year of 365 days, with 12 months of 30 days ; the day was shared into 12 hours for the day and 12 hours for the night (Andre-Leicknam, Ch. IV). It's an example of isochronism.

In Rome : Plutarch writes that before Caesar, the relation between year and month was very confused. (Life of Caesar, $59,2)$ : the year had ten months until the reign of Numa (c.715-c.672). (Life of Numa, 19, 1). In The other prayer to the calends of January (379 AD), the Consul Ausonius was the first in Rome who associated the regular coming of the seasons with Annus (year). (Conteneau : p. 553). The Calends where the first day of the lunar month. The Romans used to inscribe the names of the two consuls of the year on the amphoras, in order to date the wines : it was called consular year.

\section{..WINTER...SPRING...SUMMER...AUTUMN...WINTER...SPRING.. (-.....4 homeric years....... $\langle\ldots . . . . \cdot$ current year.......-$\rangle$}

Figure 2: The Homeric year compared with our current year.

In Greece: Plutarch points out that among some barbarians (people who did not speak Greek), the year had three months ; for Arcadians of Peloponnese the year had four months, and that of Acarnanes had six months (Life of Numa, 18,6). Plutarch reports that Philippides affirm that Stratocles reduced the year to one month. (Life of Demetrius, 26, 5). In the Odyssey, the Greek poet Homer (8th century BC) writes this incredible verse: when the fourth year came, when the seasons started again. (Song II). In clear, the return of the seasons took place every four years. (Figure 2): the homeric year had three months. During the 8th century BC in Greece, the year had three months. In Mesopotamia : The year was used immediately at the end of the third millennium ; it had 360 days (Andre-Leicknam : Ch. IV).

In the Assyrian period ( $12^{\text {th }}-7^{\text {th }}$ century BC), the limmu were important people who were inscribed on a list ; their name was used to designate the year. (Chevalier, p.239) The erratic values of the year probably explains the extravagant age reached by the biblical patriachs: Adam, 930 Seth, 918 Enos, 905 Mahalalêl, 895 Yered, 968 Henoc, 365 Mathusalem, 969 Lamec, 777 Noe, 950 Sara, 177 Abraham, 175. (Wogue).

Predominantly, it proves that the year does not exist in the nature.

\section{Modern times}

Definition of the day : in 1840, A. Tarbe gave an exemplary définition: The returns of the Sun (observed) to the meridian mark the days (concept) (Title IV, §8). The phenomenon described by Tarbe leads to a coherent definition:

The day is a unit which corresponds to the return of the Sun to the meridian

Definition of the second : in 1967, for the purpose of accuracy, the Conference Generale des Poids et mesures decided: The time unit of the International System of Units is the second defined as follows: "The second is the duration of 9,192,631,770 periods of the radiation corresponding to the transition between the two hyperfine levels of the ground state of the Cesium 133 atom". Unfortunately, this wording contains two formal defects:

a) The period is defined as the "duration of a cycle". Therefore, "duration of a period" (duration of the duration of a cycle) is a pleonasm.

b) The duration has not been defined anywhere; therefore the word duration may not be used in such an important definition.

The consistant definition is:

The second is a unit which corresponds to 9,192,631,770 Cesium cycles..

It is to be emphasized that Sigi, kin, olympiad, lunar month, year, day, second, don't exist in nature, they are constructions of the mind. The non existence of time units will lead to the non existence of time.

\section{References}

1. André Leicknam B, Ziegler C (1982) Naissance de l'écriture; cunéiformes et hiéroglyphes, The birth of writing; cuneiform and hieroglyphs. Réunion des Musées Nationaux.

2. Brion M (1949) La Résurection des Villes Mortes.

3. Chevalier J, Gheerbrant A (1973) Dictionnaire des Symboles.

4. Conteneau G (1937) La Civilisation d'Assur et de Babylone. pp. 1-559.

5. Dieterlin G, D Sylla (1992) L'Empire de Ghana (Kartala-Arsan).

6. Flavius Yossipos (1968) Histoire Ancienne des Juifs (Acient History of the Jews).

7. Herodotus (1964) L'Enquête (The Histories).

8. Plutarch (2001) Vies Parallèles (Parallel Lives).

9. Tarbé A (1840) Nouveau Manuel Complet des Pois et Mesures, des Monnaies, du Calcul Décimal, et de la Vérification (New complete manual of weight and measurements, currencies, decimal calculation, and verification).

10. Wogue L (1966) Thora (Société Encyclopédique Française - Paris 1966 - translation from Hebrew into French by Lazare Wogue, Grand Rabbi). 
This work is licensed under Creative Commons Attribution 4.0 License DOI : $10.19080 /$ JFSCI.2017.06.555690
Your next submission with Juniper Publishers will reach you the below assets

- Quality Editorial service

- Swift Peer Review

- Reprints availability

- E-prints Service

- Manuscript Podcast for convenient understanding

- Global attainment for your research

- Manuscript accessibility in different formats ( Pdf, E-pub, Full Text, Audio)

- Unceasing customer service

Track the below URL for one-step submission https://juniperpublishers.com/online-submission.php 